\title{
ZINC-HEMOCYANIN BINDING IN THE HEMOLYMPH OF CARCINUS MAENAS (CRUSTACEA, DECAPODA)*
}

\author{
J.-L. M. Martin ${ }^{1}$, A. Van Wormhoudt and H. J. Ceccaldi ${ }^{2}$ \\ 'C.O.B., B.P. 337. 29273 Brest-Cedex, France and \\ ${ }^{2}$ E.P.H.E., Station marine d'Endoume, 13007 Marseille. France
}

(Received 19 January 1977)

\begin{abstract}
A quantitative and electrophoretic study of copper and zinc in hemolymph of the crustacea decapoda, Carcinus maenas, has been carried out.

2. Most of the copper was linked with hemocyanin.

3. All copper-binding proteins are hemocyanin.

4. Zinc belongs to three different compartments: more than $68 \%$ is linked with hemocyanin; about $10 \%$ is shown in the fraction containing blood cells, lipids and carotenoids; $15 \%$ is present in the hemolymph under a soluble and dialysable form.

5. Specific zinc-binding protein has not been found out in the serum of Carcinus maenas

6. Zinc linked with hemocyanin is found on high molecular weight protein fractions only. -
\end{abstract}

\section{INTRODUCTION}

A very strong correlation exists between the quantitative variations of copper and that of zinc present in the crustacean decapods (Martin, 1974). This correlation is the consequence of a similar metabolism of these two metals in the hemolymph during the different stages of the intermolt cycle. The existence of a possible binding between the respiratory pigment, hemocyanin, and zinc at the macromolecular level, has already been postulated (Martin, 1975). The aim of this paper is to give an evidence of such a binding.

So far, the term "hemocyanin" has not been defined precisely. Many workers used this term as a synonym of copper-protein. Since the respiratory properties of such a protein and its fractions are not clearly defined, in the present work we call "hemocyanin" the protein fractions of the hemolymph of the decapod crustacean studied in the present work, exhibiting a specific copper coloring reaction, and also reacting with a solution of benzidine and hydrogen peroxide (Ghiretti, 1956).

\section{MATERIAL AND METHODS}

\section{Electrophoretic study}

Electrophoretic separation of serum proteins of Carcinus maenas $L$. has been carried out by using a hydrolysed starch gel and also a polyacrylamide gel known as "Gradipor". Latter is formed from the anode to the cathode of polyacrilamide having increasing concentrations from 5 to $20 \%$ A buffer solution, pH 7.9, made by "tris" ( 2 aminohydroxymethyl. 1.3 propanediol) is used for protein migration at the temperature of $4^{\circ} \mathrm{C}$.

These two types of gel, starch and polyacrilamide, are in the form of plates, and permit a large electrophoretic migration. When the migration is completed. the gel is cut into longitudinal bands which are used for specific colorations. These different bands, resulting from the same electrophoregram, exhibit protein patterns perfectly comparable with each other.

* Contribution No. 511 du Département Scientifique du Centre Océanologique de Bretagne.

\section{Specific colorations}

Total proteins are confirmed by using an acetic solution of $5_{\infty}^{\circ}$ amido-black.

Copper-protein fractions are confirmed using the methods of potassium ferrocyanide. of ammonium and of tetraethylene-pentamine as described by Furman (1962). We have also used the method of the $1 \%$ rubanic acid, which method is more commonly used (Whittaker. 1959 ; Decleir, 1961; Cowden \& Coleman, 1962; Busselen, 1970).

Zinc-protein fractions are confirmed by the test described by Langeron (1949). The electrophoregrams are placed in a $10 \%$ solution of sodium nitroprussiate at $50^{\circ} \mathrm{C}$ for $1 \mathrm{hr}$. Then, the gels are washed in tap water for $15 \mathrm{~min}$ before placing them in potassium sulphide solution.

Hemocyanin fractions are detected by using the method of Manwell \& Baker (1963), in which hemocyanin reacts with benzidine solution (3-3' dimethoxybenzidine) and hydrogen peroxide (Ghiretti, 1956).

Separation of different constituants of hemolymph

The method of precipitating hemocyanin at the iso-electric point (Rawlinson, 1940), modified by Godbillon \& Frentz (1972) has been used.

Approximately, $20 \mathrm{ml}$ of hemolymph has been taken from several male crabs, at the stage $\mathrm{C}_{4}$ of the intermolt cycle, by cutting a dactylopodite. The small amount of fibrin present in the hemolymph is taken out and conserved for analysis. To the $20 \mathrm{ml}$ hemolymph $0.1 \mathrm{~g}$ of potassium oxalate in $5 \mathrm{ml}$ water has been added. Potassium oxalate acts as an anticoagulant preventing the formation of blood clotting.

An equal volume of potassium acetate buffer solution. $\mathrm{pH} 4.6$, is added to the hemolymph. The buffer solution contains $68 \mathrm{~g}$ of hydrated sodium acetate and $28.4 \mathrm{~g}$ of glacial acetic acid per litre of water. As this solution contains equimolecular quantities of salt and acid, its pH will not be changed by dilution.

The hemolymph solutions is then placed in a cold room at the temperature of $2-4^{\circ} \mathrm{C}$ for $1 \frac{1}{2} \mathrm{hr}$. During this period. an orange-yellow precipitate, rich in lipids, carotenoids and blood cells, decants and is taken out by centrifuging. The remaining blue liquid is dialysed against distilted water for $72 \mathrm{hr}$. The blue precipitate corresponding to hemocyanin crystals and decanting during dialysis is washed several times with distilled water and recovered by successive centrifuging. The concentrations of copper and zinc have been determined in such hemocyanın crys. 


\section{J.-L. M. Martin, A. Van Wormhoudt and H. J. Ceccaldi}

Table 1. Distribution of copper and zinc in the different fractions of the hemolymph of Carcinus maenas. The values are expressed in $\mu \mathrm{g} / \mathrm{g}$ tissue

\begin{tabular}{|c|c|c|c|c|c|}
\hline Hemolymph & (1) & $\begin{array}{c}\mu \mathrm{Cu} \\
44.72\end{array}$ & $\underset{32.25}{\mu \mathrm{g}} \mathbf{Z n}$ & $\begin{array}{c}\% \text { of total } \\
\mathrm{Cu} \\
100\end{array}$ & $\begin{array}{l}\% \text { of total } \\
\mathrm{Zn} \\
100\end{array}$ \\
\hline $\begin{array}{l}\text { Fibrin } \\
\text { Centrifuge precipitate } \\
\text { (blood cells. }\end{array}$ & (2) & 2.09 & 2.29 & 4.67 & 7.10 \\
\hline lipids. carotenoids) & (3) & 0.38 & 3.14 & 0.85 & 9.74 \\
\hline Hemocyanin & (4) & 41.57 & 22.03 & 92.96 & 68.32 \\
\hline Total $(2)+(3)+(4)$ & & 44.04 & 27.46 & 98.48 & 85.16 \\
\hline
\end{tabular}

tals and in the different constituents of hemolymph isolated by the above technique.

\section{Determination of copper and zinc concentrations}

Copper and zinc in the total hemolymph and in its different constituents are determined by using an atomic absorption spectrophotometer (Perkin- Elmer. model 303). The conditions of analysis are as those described by Slavin (1968).

\section{RESULTS}

Table 1 shows total content and percentage of copper and zinc present in the hemolymph and in its different constituents. Four samples of $20 \mathrm{ml}$ hemolymph of Carcinus maenas, at stage $\mathrm{C}_{4}$, have been analysed. The hemocyanin fractions contains the highest concentration of copper and zinc. In the total content of copper and zinc present in the hemolymph. $93 \%$ of copper and $68.3 \%$ of zinc belong to hemocyanin. The centrifuge precipitate, containing blood cells. lipids and carotenoids, obtained after the first dialysis contains only a low amount of copper. $0.85 \%$ of total copper. Nevertheless, the same fraction contains 4.67 and $7.10 \%$ of total copper and zinc respectively. It can be noticed that the total of the different constituants represents $98.55 \%$ of total copper in hemolymph, but only $85.16 \%$ in the case of zinc.

Figure 1 shows the starch gel electrophoregrams obtained with the serum of male Carcinus maenas at stage $\mathrm{C}_{4}$ of the intermolt cycle. The protem fractions have been numbered from 1 to 6 according to the speed of migration, from the fastest with low molecular weight to the slowest with high molecular weight. only those fractions showing particular interest into

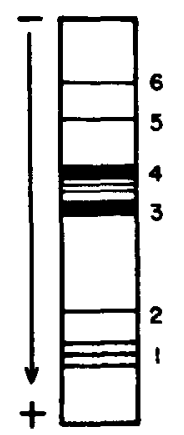

(0)

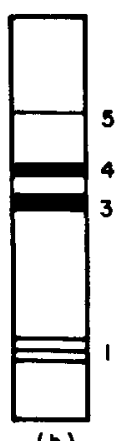

(b)

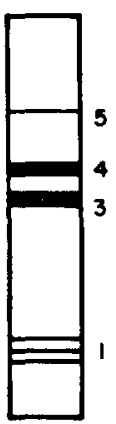

(c)
Fig. 1. Hydrolysed starch gel electrophoregram of serum proteins of Carcinus maenas. (a): Total proteins; (b) hemocyanin; (c) copper protein fractions. the present study and only those which are distinctly separated from other fractions are numbered. Thus, certain numbers represent a group of many fractions.

On the electrophoregram (a), corresponding total proteins, 6 fractions or groups of fractions are shown. The fraction 1 with fast migration represents a group of at least 3 fractions. The fractions 3 and 4 are those showing the strongest intensity. The electrophoregrams (b) and (c) show the hemocyanin fractions and the copper protein fractions respectively. These two electrophoregrams are fully identical. For each of them. 4 fractions or groups of fractions are exhibited.

The electrophoregrams represented in Fig. 2, have been carried out on polyacrylamide gel. On electrophoregram corresponding to the total proteins (a), 7 fractions are distinguished. This electrophoregram shows interest by comparing (b) and (c) which correspond to the fractions containing copper (b) and zinc (c). For copper (b). 5 fractions are shown, 1, 3, 4 . 5 and 6 . We notice that the most important fractions of the electrophoregram (a). 1.3.5 and 6 are copper protein fractions. Zinc has been detected in the fractions 3,5 and 6 which also contain copper. It has been noted that the fractions transporting zinc are those fractions with slow speed of migration.

\section{DISCUSSION}

The study of distribution of copper and zinc in the different constituents of the hemolymph of Carcinus maenas shows that these two metals are mainly concentrated in the hemocyanin fractions: $93 \%$ of copper and $68 \%$ of zinc. In the case of copper, this result is inferior to those generally admitted. Andrews (1967) has pointed out that hemocyanin copper represents

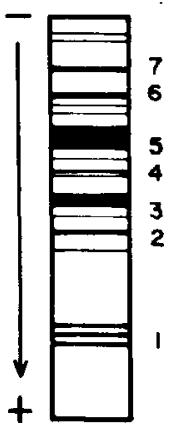

(a)

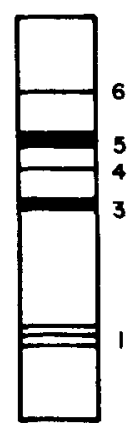

(b)

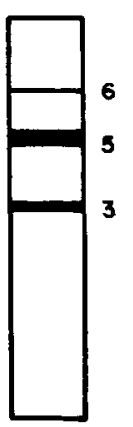

(c)
Fig. 2. Polyamylamide gel electrophoregram of serum proteins of Carcinus maenas. (a): Total proteins: (b) copper protein fractions; (c) zinc protein fractions. 


\section{Zinc-hemocyanin binding}

$>99.5 \%$ of total copper content in the hemolymph. The method of separation we have used here seems to be a reason for such a difference. The formation of a small amount of fibrin and also the centrifugation of serum components other than hemocyanin might have created an error. During the separation of these components, there is a possibility of losing hemocyanin. which may correspond to 4.67 and $0.85 \%$ of copper measured in the fibrin and in the centrifuge precipitate containing blood cells, lipids and carotenoids, respectively.

The total of the different percentages of zinc determined in the various compartments is $85.2 \%$ of total zinc in the hemolymph. The analysis of this metal has been carried out in the same samples as for that of copper. for which only $1.5 \%$ of the total copper has not been recovered. The unrecovered $14.8^{\circ}$ of zinc. therefore, has been lost during the course of dialysis. This metal has been detected only in the hemocyanin which are non-dialysable proteins. Therefore, the $14.8 \%$ of total zinc not recovered is in the hemolymph in a soluble dialysable form.

The electrophoretic study of the hemocyanin of the serum of Carcinus maenas shows that in the 6 fractions or groups of fractions isolated in the hydrolysed starch gel. 4 of them are hemocyanin. The number of isolated hemocyanin fractions in the case of the present study corresponds with the results obtained utilising the same method by Inoue \& Motohiro (1969) in different species of crustucean decapods. Three fractions are isolated in Paralithodes camtschaticas, 4 in Erimacrus isenbeckii and 5 in Chionoecetes opilio. Ghidalia et al. (1971) showed in Macropipus puber that in 14 protein fractions isolated, 4-9 are copper protein fractions and, therefore, are hemocyanin. The results obtained by these authors and by us cannot be easily compared. As a matter of fact, Busselen (1970) has shown that for the same serum and also using the same electrophoretic technic. the number of hemocyanin fractions can vary in Carcinus maenas in a ratio of $1-4$, according to the $\mathrm{pH}$ of the buffer used. This author has reported the hypothesis of breaking of hemocyanin molecules when the $\mathrm{pH}$ increases. Nevertheless, there is no doubt that all the protein fractions transporting copper are hemocyanin. This result is in accordance with the observations of Cowden \& Coleman (1962).

The present electrophoretic study of the serum of Carcinus maenas shows that in the electrophoregram. in all cases, zinc is detected on hemocyanin fractions. It can be concluded that there is no specific zinc protein fractions. detectable by the electrophoretic method. in the serum of such a species. The link zinchemocyanin explains the observed correlations between the concentrations of copper and that of zinc in the hemolymph (Martin, 1975)

Many hypothesis can be made to explain such a link between zinc and hemocyanin. One point of view may be that the metal may form an integrated part of the molecule, and would play a role, directly or indirectly, in relation with the function of the molecule. that is to say the transport of oxygen.

On the other hand. we have shown that all copper proteins are hemocyanin. Five fractions or groups of fractions have been isolated in the serum of Carcinus maenas. These 5 fractions are in fact unit-fractions coming from a "mother-unit" which has been broken by different physico-chemical parameters. such as $\mathrm{pH}$. during the course of electrophoresis (Busselen, 1970). The present study reveals that zinc is detected only in slow moving protein fraction, that is to say fractions with high molecular weight. Therefore, the zinc could act as an element to permit or stabilise the quaternary structure of hemocyanin (HernandezMoran et al., 1966) and as a link between the unitfractions.

\section{REFERENCES}

ANDRFws P. (1967) Uher den Blutchemismus des Flubkrebses Orconectes Limosus und seine Veränderung im Laufe des Jahres. Z. vergl. Physiol. 57, 7-4.3.

Busselen P. (1970) Effects of moulting cycle and nutritional conditions on haemolymph proteins in Carcinus maenas. Comp. Biochem. Physiol. 37A. 73-83.

Cowden R. R. \& Coleman J. R. (1962) A starch gel electrophoretic study of the hemolymph proteins of some Bermuda crabs. Experientia 18, 265266.

DECLEIR W. (1961) The localisation of copper in agar-gel Electrophoretic patterns of crustacean blood. Naturwissenschaften 48, $102 \quad 103$

Furman N. H. (1962) Standard Methods in Chemical Analyses. 6th edn. Vol. 1. Van Nostrand. New York.

Ghidalia W. Vendrfly R. \& Monti de Reze M. (1971) Electrophoretic analysis of Macropipus puher crustacea male serum: the copper fractions. Comp. Biochem. Physiol. 40A. 479 . 485.

GHIRETTI F. (1956) The decomposition of hydrogen peroxide by hemocyanin and by its dissociation products. Archs Biochem. Biophys. 63, 165-176.

GodillLon G. \& FRENTZ R. (1972) Les méthodes de préparation de l'hémocyanine du crustacé décapode Car. cinus maenas L. Bull. Acad. Soc. Lorr. Sci. 11. 110.

Hernandez-Moran H. van BrugGen E. F. J. \& Ohtsuk M. (1966) Macromolecular organisation of haemocyanins and apohaemocyanins as revealed by electron microscopy. J. molec. Biol. 16, 191207.

Inove N. \& Motohiro T. (1969) Starch gel electrophoresis of crab hemocyanins. Bull. Jap. Soc. Scl. Fish. 35. 559.561.

Langeron M. (1949) Précis de Microscopie. Masson et Cie. Paris.

MaNwell C. \& BaKer C. M. (1963) Starch gel electrophoresis of sera from some marine arthropods: studies on the heterogeneity of haemocyanin and on a "ceruloplasmin-like protein". Comp. Biochem. Physiol. 8, 193-208.

Martin L. J. M. (1974) Metals in Cancer irrogatus (crustacea decapoda): concentrations. concentration factors. discrimination factors, correlations. Mar. Biol. 28 , 245- 251.

Martin L. J. M. (1975) Le cuivre et le zinc chez Cancer irroratus (crustacé décapode): métabolisme compare au cours du cycle dintermue. Comp. Biochem. Physiol. 51A. $577-584$.

RAWLINSON W. A. (1940) Crystalline haemocyanin: some physical and chemical constants. Aust. J. exp. Biol. med. SC. 18. 1.31 140.

Slavin W. (1968) Atomic Absorption Spectroscopy. Interscience. New York.

WHITTAKER J. R. (1959) Localisation of haemocyanın on starch gel electrophoretic patterns. Nature. Lond. 184. 193. 194. 